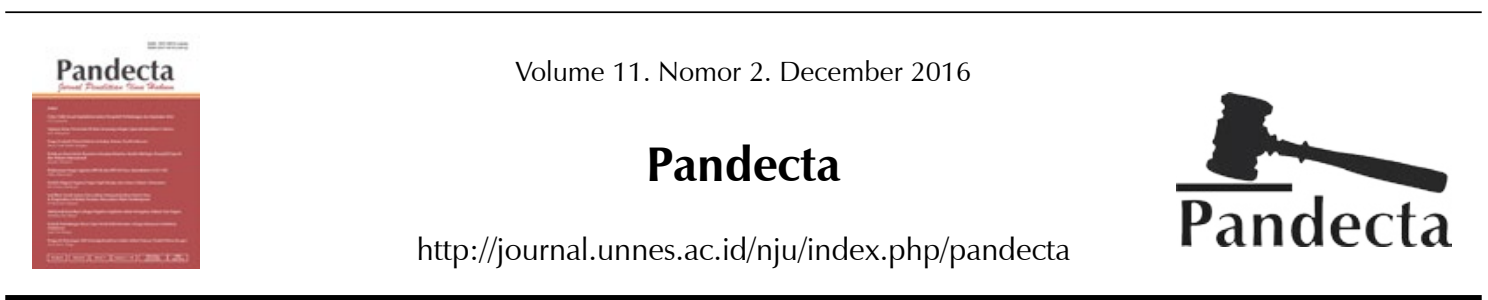

\title{
Ideologi Etis Penyingkap Korupsi Birokrasi
}

\author{
Arif Awaludin $\bowtie$ \\ Fakultas Hukum Universitas Wijayakusuma Purwokerto, Jawa Tengah, Indonesia \\ DOI: http://dx.doi.org/10.15294/pandecta.v11i1.7852
}

\begin{tabular}{l} 
Info Artikel \\
\hline Article History: \\
Received : June 2016; \\
Accepted: November 2016; \\
Published: December 2016 \\
\hline Keywords: \\
ideologi etis; korupsi bi- \\
rokrasi; penyingkap korupsi
\end{tabular}

\begin{abstract}
Abstrak
Birokrasi dan korupsi ibarat dua sisi mata uang. Dimana ada birokrasi disitu ada korupsi. Menyingkap korupsi di lingkungan birokrasi bukanlah perkara mudah, hal itu butuh "orang dalam" untuk menyingkap korupsi tersebut, mereka adalah aparatur sipil negara. Oleh sebab itu, tindakan whistleblowing sangat dibutuhkan untuk menyingkap kasus korupsi birokrasi. Keputusan seorang aparatur sipil Negara untuk menyingkap korupsi adalah keputusan yang didasarkan ideologi etis. Keputusan ideologi etis menjadi modal utama bagi seorang penyingkap korupsi (whistleblower). Penelitian bertujuan untuk mengungkap alasan para aparatur sipil Negara tersebut dalam menyingkap korupsi yang terjadi di lingkungan kerja mereka, serta mendeskripsikan tindakan mereka dalam menyingkap korupsi birokkrasi. Penelitian dilakukan dengan pendekatan socio legal research, informan penelitian ini adalah para aparatur sipil negara yang menyingkap korupsi birokrasi di Jawa Tengah. Hasil Penelitian ini menunjukkan bahwa alasan pribadi dan lingkungan merupakan alasan para aparatur sipil negara dalam menyingkap korupsi. Ideologi etis sangat berperan dalam mengungkap terjadinya penyimpangan di tempat kerja, termasuk korupsi birokrasi. Idealisme menjadi pertimbangan etis bagi para penyinngkap korupsi birokrasi. Tipologi ideologi etis yang dimiliki para penyingkap korupsi birokrasi ini adalah Idealisme Absolutists. Idealism absolutis yang dimiliki para whistleblower menjadikan mereka sebagai pihak yang dimusuhi dan disingkirkan di lingkungan birokrasi. Sangat disayangkan, tindakan mereka menyingkap korupsi birokrasi belum mendapat perlindungan hukum.
\end{abstract}

\begin{abstract}
Bureaucracy and corruption are like two sides of a coin. Where no bureaucracy there is no corruption. Exposing corruption within the bureaucracy is not easy. Need an "insider" to expose corruption, they are civilian state apparatus. Whistleblowing action is needed to expose the corruption of the bureaucracy. The decision of a civilian state apparatus to expose the corruption is unethical decision based ideology. Decision ethical ideology is the main basis for a personally-corruption (whistleblowers). The research aims to uncover the reasons the civilian apparatus of the State in exposing corruption in their working environment, and to describe their actions in exposing corruption birokkrasi. The study was conducted with the approach of socio legal research, informants of this study is the civilian state apparatus that exposed the corruption of the bureaucracy in Central Java. Research shows that personal and environmental reasons is the reason the civilian apparatus of the state in exposing corruption. Ethical ideology was instrumental in uncovering of irregularities in the workplace, including bureaucratic corruption. Idealism becomes penyinngkap ethical considerations for bureaucratic corruption. Typology ethical ideology personally owned the bureaucratic corruption are Absolutists Idealism. Absolutist idealism owned by the whistleblower make them as those who despised and excluded within the bureaucracy. Regrettably, their actions expose the corrupt bureaucracy has legal protection.
\end{abstract}

$\triangle$

Address : Jalan Raya Beji-Karang Salam Purwokerto, Jawa Tengah Indonesia, 53152

Email: Arifawaludin@gmail.com
(C) 2016 Universitas Negeri Semarang ISSN 1907-8919 (Cetak) ISSN 2337-5418 (Online) 


\section{Pendahuluan}

Demokrasi modern memiliki beberapa mekanisme untuk mengekspos tindakan ilegal atau tidak bermoral dan praktek-praktek yang merusak masyarakat. Sejak tahun 2000, ada banyak skandal keuangan profil tinggi yang melibatkan kegiatan kecurangan pelaporan keuangan. Para korban skandal ini termasuk karyawan, investor, dan masyarakat luas. Salah satu metode yang paling efektif mendeteksi penipuan dan pencegahan adalah pengungkapan oleh karyawan (whistleblowing) (Brink, 2015:180). Pelaku yang melakukan tindakan penyingkapan (whistleblowing) dikenal dengan nama whistleblower. Saat ini terjadi peningkatan pengakuan akan peran para whistleblower yang menyingkap informasi kepada publik karena adanya penyimpangan, pelanggaran hukum dan etika, korupsi atau situasi berbahaya lainnya. Fenomena ini tidak hanya mencakup masalah kriminal (pidana) tapi mencakup bidang yang lebih luas.

Konferensi Internasional Anti Korupsi ke-13 di Athena Yunani menegaskan arti penting perlindungan terhadap whistleblower yaitu sebagai persyaratan Internasional, konsekuensi logis dari suatu kewajiban dan persyaratan khusus. Saat ini pusat perhatian pemberantasan korupsi masih pada tataran penindakan, sedangkan pencegahan dan deteksi dini adanya korupsi belum mendapat perhatian. Adanya ratifikasi Convention Against Corruption 2003 pada bulan Desember 2003 di New York, maka seharusnya ada perubahan strategi pencegahan dan pemberantasan korupsi yang disesuaikan dengan konvensi tersebut.

Praktik korupsi dilakukan secara tertutup. karena mengandalkan kerahasiaan, kolusi dan sedikit kepercayaan agar transaksi haram itu tidak bocor ke luar. Dalam kasuskasus yang paling mencolok pun, korupsi jarang dilakukan secara terbuka. Ibarat suatu organisme, bakteri yang berkembang biak di lingkungan yang hangat dan gelap. Korupsi beroperasi dan berkembang biak di lingkungan yang bersahabat. Korupsi tidak pernah berhenti berkembang biak dalam suatu siklus reproduksi serta sulit dideteksi. Korupsi juga menyebarkan virus-virus yang mematikan. Seperti halnya bibit penyakit, korupsi juga akan menyerang fungsi-fungsi vital dari berbagai organ birokrasi. Jika tidak segera diobati, korupsi dapat melumpuhkan fungsi berbagai organ birokrasi tersebut.

Mencermati eskalasi korupsi yang semakin tinggi intensitasnya dalam tubuh birokrasi, maka fakta itu (korupsi) seharusnya berani diungkap sehingga dapat dijadikan pengalaman untuk memperbaiki pola pikir dan perilaku, bukannya ditutupi, ditekan, dan dipaksakan untuk dilupakan (Rahardjo, 2005:12). Korupsi birokrasi adalah istilah yang dipopulerkan oleh Gerald E. Caiden yaitu I have deliberately used the term "bureaucratic corruption" instead of "administrative corruption" to refer to those forms of corruption that are clearly committed by public administrators in their official capacity, not in their personal or, where applicable, their political capacity Furthermore, I have distinguished bureaucratic corruption from maladministration to indicate that fraud, waste and abuse, and other forms of maladministration, may not be the fault of bureaucratic corruption. Bureaucratic corruption minimally includes bending the law, discarding morality, employing deception and justifying criminality, and would also include dishonesty, venality, nepotism, appointment of jobs and contracts to unqualified persons, awarding decisions and services in exchange for bribes and kickbacks, and government by favour, all of which involve fraud, waste and abuse in government (Caiden, 1980:56). (Saya sengaja menggunakan istilah "korupsi birokratis" bukan "korupsi administrasi" untuk merujuk kepada bentuk-bentuk korupsi yang nyatanyata dilakukan oleh administrator publik dalam kapasitasnya yang resmi, bukan pribadi atau, dalam hal kapasitas politiknya. Selain itu, saya membedakan korupsi birokrasi dari mal-administrasi untuk menunjukkan bahwa penipuan, pemborosan dan penyalahgunaan, dan bentuk lain dari maladministrasi, mungkin bukan kesalahan korupsi birokratis. Korupsi birokratis minimal mencakup pembengkokkan hukum, penyingkiran moralitas, penggunaan muslihat dan pembenaran kejahatan, dan juga mencakup ketidakjujuran, 
penyuapan, nepotisme, penunjukan pekerjaan dan kontrak untuk orang tidak memenuhi syarat, pemberian keputusan dan jasa yang dipertukarkan dengan suap dan pengembalian, dan pemerintah dengan mendukung, Semua yang melibatkan penipuan, pemborosan dan penyalahgunaan kekuasaan dalam pemerintahan).

Bentuk-bentuk korupsi birokrasi dalam pelayanan publik dapat diidentifikasi dari perilaku-perilaku seperti suap, penggelapan, penyalahgunaan wewenang, perolehan barang atau jasa secara ilegal, tidak masuk akal, pemalsuan, kualitas layanan yang buruk, dan kecerobohan.

Korupsi yang merajalela dalam sistem birokrasi Indonesia, salah satu sebabnya karena adanya model birokrasi patrimonial yang dianut oleh Indonesia, sebagaimana dikemukakan oleh Weber, birokrasi patrimonial ialah suatu sistem birokrasi dimana jabatan dan perilaku dalam keseluruhan hirarki birokrasi lebih didasarkan pada hubungan familier, hubungan pribadi dan hubungan 'bapak-anak buah' (patron client) (Muhaimin, 1990:21).

Para pekerja yang berada dalam lingkunngan birokrasi pemerintah disebut dengan Pegawai Negeri Sipil (PNS). la adalah salah satu jenis Kepegawaian negeri di samping Anggota TNI dan Anggota Polri (UU No 43 Tahun 1999). Pengertian Pegawai Negeri adalah warga negara RI yang telah memenuhi syarat yang ditentukan, diangkat oleh pejabat yang berwenang dan diserahi tugas dalam suatu jabatan negeri, atau diserahi tugas negara lainnya, dan digaji berdasarkan peraturan perundang-undangan yang berlaku (Pasal 1 ayat (1) UU No.43 Tahun 1999), setelah diterbitkannya UU Nomor 5 Tahun 2014 tentang Aparatur Sipil Negara istilah PNS diubah menjadi Aparatur Sipil Negara (ASN).

Menurut Ketentuan Umum Pasal 1 butir (1) Aparatur Sipil Negara yang selanjutnya disingkat ASN adalah profesi bagi pegawai negeri sipil dan pegawai pemerintah dengan perjanjian kerja yang bekerja pada instansi pemerintah.UU ini memperluas cakupan tentang pegawai negara, yang tidak hanya PNS tapi juga pegawai pemerintah dengan perjanjian kerja yang bekerja pada instansi pemerintah.
Lembaga birokrasi sebagai organ Negara yang menangani sektor pelayanan publik ditengarai banyak pihak menjadi sarang korupsi. Arbi Sanit mengatakan babwa pelaku birokrasi (birokrat) mempunyai wewenang yang sangat besar, yang memunculkan dikotomi antara pembuat kebijakan dan pelaksana kebijakan, sehingga birokrasi lebih mengedepankan sikap menguasai daripada melayani masyarakat. Tatkala semua aspek kehidupan masyarakat ditangani oleh birokrasi, maka layanan birokrasi justru menjadi lahan subur bagi birokrat untuk melakukan korupsi, kolusi, dan nepotisme (KKN), sebab pejabat politik yang mengisi birokrasi pemerintan sangat dominan (Sanit, 2006:122).

Tidak mudah untuk mengungkap korupsi yang terjadi di lingkungan birokrasi pemerintah. Butuh adanya petunjuk dari orang dalam yang menyingkap korupsi ini ke publik. Survei yang dilakukan ACFE (Association of Certified Fraud Examiner) antara 2010 hingga 2014 terhadap 106 negara menunjukkan bahwa korupsi (sebagai salah satu jenis Fraud) lebih banyak terungkap karena adanya informasi (TIP/petunjuk) yang diberikan oleh orang dalam perusahaan atau organisasi, Tahun 2010 sebanyak 40,2\%Tahun 2012 sebanyak 43,3\% dan tahun 2014 sebanyak $42,2 \%$. Sedangkan menurut hasil survey Tahun 2014, sumber informasi adanya penyimpangan diberikan oleh pegawainya sendiri sebesar $49 \%$. Ini membuktikan bahwa petunjuk (TIP) adalah jalan yang paling efektif dalam pemberantasan korupsi sejak dini (http://www.acfe.com diakses terakhir pada 31 Agustus 2016).

Keberanian seseorang dalam menyingkap korupsi sangat ditentukan oleh filsafat moralnya. Filsafat moral pribadi sangat penting untuk memahami penilaian dan perilaku etis. Sebagai integrasi sistem moral, konsep ideologi etis terdiri dari keyakinan, nilai-nilai, standar, dan gambar pribadi yang individu memposisikan diri untuk dua sisi mata uang yang sama benar dan salah (Pekdemir dan Turan, 2015:35).

Etika atau 'ethics' merupakan satu cabang filsafat yang memperbincangkan tentang perilaku benar dan salah (right and wrong) dan baik dan buruk (good and evil), 
dan bahkan relasi-relasi sosial (social relations) dan makna keberagamaan (religious meaning) dalam hidup manusia (Gordon Graham, 2010: 3). Etika terapan (applied ethics) yang berkembang dewasa ini ialah sistem etika di sektor publik dan penyelenggaraan kekuasaan negara. Inilah yang biasa dinamakan dengan istilah "government ethics" (Asshiddiqie, 2016), ataupun "ethics in public administration" yang sering disalahpahami seakan-akan hanya berkenaan dengan etika pemerintahan dalam arti sempit, yaitu terkait para pejabat di lingkungan pemerintahan eksekutif saja.

Namun, dalam pengertian bahasa Inggeris Amerika, 'government ethics' yang dimaksud adalah dalam arti yang luas, yaitu mencakup keseluruhan aspek sistem norma etika yang mengikat dan menuntun bagi para penyelenggara kekuasaan negara secara keseluruhan (Herman Eds. Mertins,1999). Ethical ideology is termed an integrated ( Ideologi etis adalah sistem etika terpadu, yang menyediakan pedoman untuk penilaian etis, cara mengatasi dilemma etis dan resep untuk tindakan dalam situasi dilema etis (Forsyth, 1980: 175-184), sementara whistleblowing adalah suatu tindakan dalam situasi dilemma etis.

Ideologi etis didefinisikan dengan konsep yang berbeda dan dimensi dalam berbagai literatur. Schlenker mendefinisikan ideologi etika dalam dua jenis yaitu; ideologi prinsip dan ideologi bijaksana (Schlenker, 2008:1078). Di sisi lain, Forsyth membedakan ideologi etis berdasarkan idealis atau relativis sikap individu (Forsyth, 1980:175).

\section{Metode Penelitian}

Penelitian dengan menggunakan pendekatan kualitatif dan socio-legal research. Penelitian sosiolegal meliputi studi tekstual terhadap peraturan perundang-undangan dan kebijakan secara kritis untuk menjelaskan problematika secara filosofis, sosiologis dan yuridis dari hukum tertulis. (Irianto dan Sidharta,2009: 109). Penggunaan metode penelitian ini untuk menjelaskan ideologi etis aparatur sipil negara saat melakukan penyingkapan korupsi birokrasi. Data primer diperoleh melalui wawancara mendalam dari para informan. Data sekunder diperoleh dari perpustakaan dan koleksi pustaka pribadi penulis yang dilakukan dengan studi pustaka atau literatur dan peraturan perundang-undangan.

\section{Hasil Penelitian dan Pembahasan}

\section{Alasan Penyingkapan Korupsi Birokrasi Di Jawa Tengah}

Whistleblowing adalah perilaku yang kemunculannya didasarkan atas persoalan etis. Nilai-nilai etika yang menjadi dasar pijakannya adalah nilai kejujuran, keterbukaan, perlindungan terhadap kepentingan umum dan penolakan terhadap penyimpangan aturan dan profesi.

Dalam riset ini para informan (Arif Awaludin, 2011) berstatus sebagai Aparatur Sipil Negara memiliki tanggung jawab dan dedikasi untuk bekerja sesuai dengan aturan dan menjunjung tinggi kejujuran. Tiga orang informan yang menjadi penyingkap korupsi birokrasi di Jawa Tengah adalah:

a. Sugeng Ibrahim, mantan Kepala Puskesmas Pamotan Kab. Rembang.

Sugeng Ibrahim, Kelahiran Tulung Agung yang tinggal di Desa Pamotan, Kecamatan Pamotan Kabupaten Rembang. Tempat ini menjadi saksi atas perjuangan seorang pemuda yang bernama Dr. Sugeng Ibrahim atau yang biasa dikenal dengan "dokter brahim". Dalam usianya yang masih belia, dia menyuarakan secara lantang atas berbagai penyimpangan yang terjadi di lingkungan pekerjaannya. Peristiwanya bermula pada tahun 1997, ketika la menjabat sebagai Kepala Puskesmas Pamotan dan berlangsung program Kebijakan Nasional tentang Pekan Imunisasi Nasional (PIN 2) dan Program Pemberian Makanan Tambahan (PMT-AS) yang merupakan sebuah proyek nasional ternyata sarat dengan korupsi. Sugeng mengungkap adanya potongan dana $20 \%$ dalam program ini oleh Birokrasi Dinas Kesehatan Rembang.

b. Murdiyanto, Kepala Sekolah SMPN 1 Mojolaban Sukoharjo.

Di era kepemimpinan Bupati Sukoharjo, Bambang Riyanto, perbuatan pak Murdiyanto mengungkap berbagai penyimpangan 
terus berjalan. Persoalan yang diungkap bukan hanya urusan yang terkait dengan pendidikan. Dia bersama dengan beberapa rekannya membuat Lembaga Swadaya Masyarakat (LSM) Peduli Sukoharjo. Kekritisannya juga membahas mengenai RSU Sukoharjo, Sepeda Motor untuk DPRD dll. Dia juga telah menyurati Kepolisian, Kejaksaan, Mahkamah Agung hingga Komisi Pemberantasan Korupsi (KPK) tentang adanya berbagai penyimpangan yang berindikasi korupsi.

Dalam kasus pungli sertifikasi, awalnya ada beberapa rekan Guru yang mengeluh karena di pungli Rp.600.000,- oleh oknum diknas terkait dengan turunnya tunjangan sertifikasi untuk guru. Mendapati kondisi tersebut, Dia mengajak teman-teman guru untuk memprotes dan melaporkannya. Namun tidak ada yang berani. Dengan inisiatif pribadi, akhirnya diputuskan untuk melaporkan kasus tersebut ke DPRD.

\section{c. Purwanto, mantan Guru SMAN 1 Sambi Boyolali.}

Dirumah yang sejuk dan berada di pinggiran kota Boyolali Pak Purwanto tinggal bersama istri dan dua anaknya. Usianya kini 52 tahun. Rumahnya disulap menjadi ruang-ruang untuk tempat kursus Bahasa
Inggris. Dengan segala kesederhanaannya Pak Purwanto memulai cerita lingkungan dinas pendidikan nasional, pemuda dan olah raga (diknaspora). Bermula dari sikap-sikap kritisnya terhadap berbagai kebijakan di lingkungan diknaspora sejak tahun 2004 hingga berakhir dengan keluarnya surat pemecatan atas dirinya dari guru PNS di Boyolali pada tahun 2010.

Purwanto menjelaskan tentang sikap dan langkahnya yang kritis, berani melawan ketidakbenaran terutama di lingkungan pendidikan. Dia menjelaskan bahwa, perlawanan Saya bukan hanya karena pengetahuan, penguatan hati nurani, pendidikan karakter. Berbekal dari orang tua, potensi pribadi dan "external force". Kegiatan ke mesjid, ke gereja dan ketempat-tempat ibadah tidak menjamin lahirnya pendidikan berkarakter. Perlawanan ini tidak bisa dilakukan sendirian, Saya bersama-sama dengan teman guru di FGB (Forum Guru Bersatu) bersama-sama menyusun perlawanan. Betul Saya yang di depan, meskipun sebetulnya saya hanya sekretaris di FGB (Awaludin, 2011).

Whistleblowing merupakan salah satu hal yang dapat terjadi dalam lingkungan organisasi. Hal yang menyimpang dari hukum dan moral itu dapat terjadi pada level ma-

Tabel 1. Profil Aparatur Sipil Negara Sebagai Penyingkap Korupsi

\begin{tabular}{|c|c|c|c|}
\hline Nama Informan & Kasus & Birokrasi & Tujuan Laporan \\
\hline Sugeng Ibrahim & $\begin{array}{l}\text { Pemotongan Dana Pronas Pekan } \\
\text { Imunisasi Nasional (PIN) II dan } \\
\text { PMT-AS }\end{array}$ & $\begin{array}{l}\text { Dinas Kesehatan } \\
\text { Kab. Rembang }\end{array}$ & Gubernur Jawa Tengah \\
\hline Murdiyanto & $\begin{array}{l}\text { Mark-up belanja barang dan } \\
\text { Pemotongan Tunjangan Sertifikasi } \\
\text { Guru }\end{array}$ & $\begin{array}{l}\text { Dinas Pendidikan } \\
\text { Nasional } \\
\text { Kab. Sukoharjo }\end{array}$ & $\begin{array}{l}\text { DPRD Kabupaten } \\
\text { dan Penegak Hukum } \\
\text { (Kepolisian dan } \\
\text { Kejaksaan) }\end{array}$ \\
\hline Purwanto & $\begin{array}{l}\text { Korupsi Dana Alokasi Khusus, Dana } \\
\text { Bantuan Operasional Sekolah, } \\
\text { Duplikasi Surat Perintah Perjalan } \\
\text { Dinas (SPPD) hingga biaya } \\
\text { pembuatan naskah ujian bersama } \\
\text { dalam Kelompok Kerja Kepala } \\
\text { Sekolah (K3S), Akal-akalan beban } \\
\text { mengajar guru guna memperoleh } \\
\text { tunjangan sertifikasi dan serta } \\
\text { sejumlah uang untuk Promosi } \\
\text { jabatan kepala sekolah }\end{array}$ & $\begin{array}{l}\text { Dinas Pendidikan } \\
\text { Nasional Pemuda } \\
\text { dan Olahraga } \\
\text { Kab. Boyolali }\end{array}$ & $\begin{array}{l}\text { Penegak Hukum } \\
\text { (Kepolisian, Kejaksaan } \\
\text { hingga KPK }\end{array}$ \\
\hline
\end{tabular}


napun dari organisasi dan diperkirakan dapat menimbulkan akibat dirugikannya kepentingan publik. Whistleblowing merupakan sebuah peristiwa yang tidak enak bagi siapapun, terutama bagi organisasi dan penyingkapnya. Whistleblowing merupakan sebuah tragedi dan itu mengindikasikan kurang etisnya organisasi. Karena itu cara menghindari terjadinya whistleblowing adalah dengan menciptakan iklim organisasi yang taat hukum dan nilainilai moral (Sudimin, 2003). Whistleblowing dikaji dari sudut pandang etika yang bertolak dari konflik nilai (clash of values) pada penyingkapnya. Konflik itu menghadapkan dua sisi antara loyalitas anggota terhadap organisasinya dan perlunya perlindungan kepentingan publik. Whistleblowing memang merupakan persoalan etis. Pergulatan etis yang dialami para whistleblower hingga keputusannya dalam menyingkap korupsi birokrasi diuraikan sebagai berikut:

a. Kisah Kepala Puskesmas yang menyingkap korupsi anggaran kegiatan Pekan Imunisasi Nasional (PIN) dan Pemberian Makanan Tambahan (PMT)

Tindakan dokter Sugeng Ibrahim untuk mengungkap kasus pemotongan anggaran kegiatan PIN 2 dan PMT dilakukan secara spontan. "Saya melihat pemotongan tersebut adalah tidak benar. Program untuk kepentingan masyarakat tidak akan tuntas. Ini merugikan kepentingan masyarakat. Saya melihatnya dengan hati nurani Saya", kata Sang Dokter. Tidak ada dalam pikirannya bahwa perbuatan tersebut terkait dengan masalah hukum atau bahkan perundangan-undangan. Hal ini terlihat sebagai sebuah protes yang spontan. Seluruh usaha tersebut tidak berhasil diungkap secara tuntas. Bayak pejabat yang mencoba menutup hlm. tersebut baik di lingkungan Dinas Kesehatan Rembang hingga Bupati Rembang saat itu.

"Tidak ada pengetahuan hukum dan langkahlangkah hukum yang seharusnya Saya lakukan. Hukum kan bicara bukti, sementara Saya hanya bereaksi saja atas adanya penyimpangan di lingkungan kerja Saya. Saya pun menyadari bahwa langkah Saya menyuarakan kebenaran, mengungkapkan penyimpangan di lingkungan Saya tidak berhasil. Kandas dihadapan hukum, yang menuntut formalitas dan bukti", keluhnya ketika tahu kasusnya tidak berlanjut ke meja hijau.

Sejak kecil Sugeng Ibrahim memang berniat menjadi dokter. la banyak membaca buku sejarah perjuangan Rakyat Indonesia yang dipelopori para dokter, seperti Tjipto Mangoenkoesoemo. "Pendidikan dokter kita sudah salah kaprah, nilai-nilai materialism dan profesionalisme telah mendominasi. Tidak ada nilai pengorbanan, perjuangan dan kepedulian yang diajarkan. Cita-cita menjadi dokter karena kepengin kaya", ungkapnya dengan nada kecewa. Dia menyatakan bahwa persoalan kesehatan, pendidikan dan kemiskinan adalah lingkaran setan yang tidak jelas ujung pangkalnya. Bidang kesehatan dipilihnya sebagai lahan perjuangan dan pengorbanan.

b. Kisah Guru yang menyingkap pungutan liar sertifikasi guru dan mark-up belanja barang.

Tindakan Murdiyanto untuk mengungkap kasus korupsi di lingkungan birokrasi di SMP 1 Sukoharjo, karena Dia mendapati berbagai perbuatan yang tidak benar, yang dilakukan Kepala Sekolah. Dia melihat ada mark up dalam pembelian barang-barang kebutuhan sekolah. Di Nota tertulis ada pembelian barang sebanyak 120 Rim Kertas, tapi ternyata barangnya hanya 24 rim kertas. Di nota juga tertulis harga satu rim, Rp.21.000,- padahlm. di pasar harganya hanya Rp.9.000,per rim. "Disini tidak hanya mark up harga bahkan mark up jumlah barang", katanya dengan nada serius. Barang-barang yang lain juga di mark up dari 300\% hingga 1000\% dari harga sebenarnya. Hal ini semua dilaporkannnya kepada Kepala Dinas.

Pendidikan madrasah dan PGA PGAA telah membentuk Pak Murdiyanto menjadi sosok yang peduli terhadap kebenaran dan anti pada penyimpangan. Ayahnya adalah petani yang pemberani. "Ayah saya ikut perang di jaman Jepang, meninggalkan sawah yang dititipkan ke saudaranya", ceritanya mengenang masa lalu. Bahkan ayah Saya mengatakan, "Jangan bohong karena itu 
adalah pangkal kehancuran". Kegiatan diluar mengajar resmi sebagai Guru di SMP Mojolaban, juga mengajar agama islam berupa pengajian tiap malam jum'at. Khutbah Jum'at juga dilakukannya di Mesjid Al Falah pada jum'at Wage, Mesjid Al Ikhlas pada Jum'at Legi dan Mesjid Sekolah pada Jum'at Kliwon. Pak Murdiyanto menjadi sosok pemberani membela kebanaran karena pe ngaruh ayahnya dan pendidikan agama yang ditempunya. "Saya melakukan itu semua dengan alasan kebenaran, bukan belas kasihan atau keinginan materi", tandasnya.

c. Kisah Guru yang menyingkap korupsi birokrasi Dinas Pendidikan

Purwanto mantan Guru SMAN 1 Sambi Boyolali bercerita tentang sikap-sikap kritisnya terhadap berbagai kebijakan di lingkungan diknaspora sejak tahun 2004 hingga berakhir dengan keluarnya surat pemecatan atas dirinya dari guru PNS di Boyolali pada tahun 2010. Beberapa kasus korupsi yang disingkap oleh Purwanto, diantaranya: a) Dana Bantuan Operasional Sekolah (BOS), b) Pemotongan anggaran hingga markup barang dan jasa terhadap Dana Alokasi Khusus (DAK), c) Duplikasi Surat Perintah Perjalan
Dinas (SPPD) hingga biaya pembuatan naskah ujian bersama dalam Kelompok Kerja Kepala Sekolah (K3S), d) Akal-akalan beban mengajar guru guna memperoleh tunjangan sertifikasi dan e) Promosi jabatan kepala sekolah yang selalu dikaitkan dengan sejumlah uang tertentu.

Perlawanan seorang Purwanto terus berjalan. Intimidasi, mutasi hingga pemecatan atas dirinya telah dialami. Dia meyakini bahwa hanya Gusti Allah yang ditakuti. Dia merasakan bahwa manusia mang harus bersikap dalam menghadapi kemungkaran. Dia mengutip hadist dan al qur'an. Perlawanan Purwanto dilakukan secara sistematis, la menggunakan lembaga-lembaga penegak hukum untuk mengatasi kasus yang dihadapinya. Kepolisian, Kejaksaan, KPK bahkan Mendiknas, Menpan dan Menkeu adalah pihak-pihak yang sudah disuratinya terkait dengan kasus ini. Bahkan ia sempat muncul dalam berita TV, SCTV sebanyak dua kali. la menggunakan kekuatan media untuk melakukan perlawanan terhadap kesewenangwenangan dan penyingkapan kasus korupsi di Boyolali.

Purwanto dikenai PP 32 Tahun 1979 tentang Pemberhentian Pegawai Negeri Sipil

Tabel 2. Alasan Mengungkap Dugaan Korupsi

\begin{tabular}{|c|c|c|c|}
\hline No & $\begin{array}{l}\text { Nama } \\
\text { Informan }\end{array}$ & Individu & Lingkungan \\
\hline 1 & Sugeng Ibrahim & $\begin{array}{l}\text { - Keyakinan beragama } \\
\text { - Sikap hidup sederhana } \\
\text { - Pendidikan keluarga } \\
\text { - Peduli terhadap kepentingan } \\
\text { sosial }\end{array}$ & $\begin{array}{l}\text { - Tidak adanya dukungan rekan } \\
\text { sejawat } \\
\text { - Kesewenang-wenangan } \\
\text { pimpinan dalam birokrasi }\end{array}$ \\
\hline 2 & Murdiyanto & $\begin{array}{l}\text { - Keyakinan beragama } \\
\text { - Sikap hidup sederhana } \\
\text { - Pendidikan keluarga } \\
\text { - Peduli terhadap kepentingan } \\
\text { rekan sejawat }\end{array}$ & $\begin{array}{l}\text { - Sedikitnya dukungan rekan } \\
\text { sejawat } \\
\text { - Besarnya dukungan } \\
\text { masyarakat baik dari } \\
\text { kalangan LSM, Ormas, DPRD, } \\
\text { Facebooker dll } \\
\text { - Kesewenang-wenangan } \\
\text { pimpinan dalam birokrasi }\end{array}$ \\
\hline 3 & Purwanto & $\begin{array}{l}\text { - Penghayatan nilai- nilai } \\
\text { agama } \\
\text { - Sikap hidup sederhana } \\
\text { - Pengetahuan dan sifat kritis }\end{array}$ & $\begin{array}{l}\text { - Tidak adanya dukungan rekan } \\
\text { sejawat } \\
\text { - Kesewenang-wenangan } \\
\text { pimpinan dalam birokrasi }\end{array}$ \\
\hline
\end{tabular}


sebagai alasan pemecatan dirinya. Dia termasuk satu-satunya orang yang dipecat dengan dasar peraturan tersebut. Ketika Dia mengurus TASPEN, pegawai Taspen pun mengakui bahwa baru petama kali menangani alas dasar pemecatan seperti ini.

Alasan mereka melakukan penyingkapan korupsi birokrasi adalah 1) Alasan Individu berupa: keyakinan, pengetahuan dan keberanian dan 2) Alasan lingkungan yang tidak kondusif.

Mengacu pada teori perilaku terencana (Theory of Planned Behavior) (Ajzen, 1991:179-211), dapat diketahui bahwa Ketiga informan ini memiliki alasan yang hampir sama dan menjadi motif mereka dalam menyingkap korupsi birokasi. Fakta seputar alasan para "penyingkap informasi" yang didasarkan pada alasan individu dan alasan sosial telah memberi dasar bagi mereka untuk mengambil keputusan mengungkap korupsi birokrasi di lingkungan kerjanya masing-masing.

Dikaitkan dengan teori yang dikemukakan oleh Albert O. Hirschman tentang loyalitas, diperoleh kesimpulan bahwa keputusan yang dilakukan para penyingkap korupsi dari Jawa Tengah ini berbeda-beda. Murdiyano memilih menggunakan mekanisme "voice" untuk melawan korupsi di Diknas Sukoharjo sedangkan Sugeng Ibrahim memilih menggunakan mekanisme "exit", sebagaimana dinyatakan olehnya bahwa:

Setelah peristiwa tersebut (penyingkapan kasus dana PIN dan PMT-AS). Saya pun berfikir bahwa Saya harus keluar dari PNS karena disini bukan tempat yang tepat untuk Saya mengabdi. Saya mendapat pengalaman berharga bahwa ternyata ada 2 tipe PNS yaitu: tipe adaptif dan tipe konfrontatif dalam mensikapi korupsi yang terjadi. Hanya dengan tipe adaptif, maka PNS tersebut akan tetap "survive", alias yang akan tetap mampu bertahan ditengah hiruk pikuk korupsi yang telah menjadi keseharian dilingkungan birokrasi. Bekerja di lingkungan birokrasi pegawai negeri sipil bukanlah pilihan yang sesuai dengan hati nuraninya. Pada tahun 2001, la mengundurkan diri dari PNS.

Di luar lingkungan birokrasi pegawai negeri Dia tetap kritis dan menyuarakan secara lantang kepentingan publik dan menyuarakan adanya penyimpangan di lingkungan pemerintah daerah Rembang, bahkan gerakan yang dilakukannya semakin sistematis dan politis. Dia memiliki loyalitas hanya kepada kepentingan publik.

Keadaan yang berbeda justru dialami oleh Purwanto. Dia diberhentikan dari pegawai negeri sipil di lingkungan Dinas Pendidikan Pemuda dan Olahraga Kabupaten Boyolali. Pemberhentiannnya bukan atas kemauannya sendiri, berbeda dengan yang dilakukan oleh Sugeng Ibrahim yang mengajukan pengunduran diri dari pegawai negeri sipil.

\section{Tipologi Ideologi Etis Para Penyingkap Korupsi Birokrasi}

Ideologi etis adalah sistem etika terpadu, yang menyediakan pedoman untuk penilaian etis la engandung unsur-unsur yang dapat diklasifikasikan yang merupakan hasil dari pengalaman-pengalaman sebelumnya ketika mengalami dilema etika (Othman \& R. Jones, 2011:752). Ideologi etis sebagai

Tabel 3.Taksonomi Ideologi Etis

\begin{tabular}{|c|c|c|}
\hline \multirow{2}{*}{ Idealism } & \multicolumn{2}{|c|}{ Relativism } \\
\hline & High Situationist & Low Absolutists \\
\hline High & $\begin{array}{l}\text { Rejects moral rules; advocates } \\
\text { individualistic analysis of each act in each } \\
\text { situation; relativistic } \\
\text { Subjectivists }\end{array}$ & $\begin{array}{l}\text { Assumes that the best possible outcome } \\
\text { can always be achieved by following } \\
\text { universal moral rules } \\
\text { Exceptionists }\end{array}$ \\
\hline Low & $\begin{array}{l}\text { Appraisals based on personal } \\
\text { values and perspective rather } \\
\text { than universal moral principles; relativistic }\end{array}$ & $\begin{array}{l}\text { Moral absolutes guide judgments but } \\
\text { pragmatically open to exceptions to theses } \\
\text { standards; utilitarian }\end{array}$ \\
\hline
\end{tabular}

Sumber: Forsyth, D. R. (1980). A Taxonomy of Ethical Ideologies. Journal of Personality and Social Psychology, 39, hal. 176 
pendekatan individu untuk penilaian etika. Forsyth mengklasifikasikan dua ideologi etis, idealisme dan relativisme, seperti kategori tinggi dan rendah (Forsyth, 1980; 175-184). Oleh karena itu kedua idealisme dan relativisme tingkat individu diklasifikasikan ke dalam empat perspektif etis yang berbeda; Situasionis, absolutis, subyektivis, dan exceptionists.

Forsyth menyatakan bahwa orientasi etika terdiri dari dua dimensi yang berbeda: idealisme dan relativisme. Dimensi idealisme mengukur tingkat di mana individu percaya bahwa konsekuensi yang diinginkan dapat, dengan tindakan yang tepat, selalu diperoleh. Dimensi relativisme mengukur sejauh mana seorang individu menolak aturan moral universal sebagai pedoman yang tepat untuk keputusan etis.

Ketika idealis yang tinggi juga menjadi menjadi relativisme yang tinggi mereka berhak sebagai 'situationist'. individu Situationist berusaha untuk mendapatkan hasil yang terbaik selama mereka bisa, namun aturanaturan moral tidak memerintah dalam segala situasi. Oleh karena itu, Situasionis mengatur perilaku atau strategi yang berkaitan dengan konteks tertentu setelah evaluasi moral berdasarkan kenyamanan mereka. Idealis tinggi dan individu relativisme rendah disebut 'absolutis', dan mereka menginginkan konsekuensi terbaik seperti Situasionis. Namun demikian, mereka mematuhi aturan moral dan membuat keputusan sesuai dengan etika mutlak.

Di sisi lain, idealis rendah dan individu relativis tinggi bernama 'subyektif'. Mereka menolak aturan moral, dan mencapai tujuan kemanusiaan tidak penting bagi mereka. Mereka mengatur perilaku mereka menggunakan keputusan moral subyektif, dan mereka tidak objektif mengevaluasi isu-isu terkait bahkan jika tindakan merugikan orang lain (Caswell, 2003). Idealis etika terakhir adalah 'exceptionists' yang berbagi idealisme rendah dan kepribadian relativisme rendah. Exceptionists juga mendukung aturan moral, tetapi mereka cenderung untuk menyeimbangkan hasil positif terhadap dampak negatif dari suatu tindakan.

Mengacu pada Taksonomi Ideologi Etis yang dikemukakan oleh Forsyth, maka dapat diketahui bahwa para penyingkap korupsi birokrasi ini termasuk dalam tipologi Idealis Absolutists (assumes that the best possible outcome can always be achieved by following universal moral rules). Mereka semua berkeyakinan bahwa aturan moral yang universal berupa kejujuran dan tanggung jawab atas sumpah jabatan sebagai aparatur sipil negara harus dijunjung tinggi. Aturan moral yang bersifat universal yaitu kejujuran harus dijunjung tinggi. Mengikuti aturan moral ini akan mendatangkan suatu kondisi yang terbaik.

Sebagai pelaksanaan dari UU tentang Kepegawaian, Pemerinttah menerbitkan Peraturan Pemerintah Republik Indonesia Nomor 42 Tahun 2004 Tentang Pembinaan Jiwa Korps Dan Kode Etik Pegawai Negeri Sipil. Pada Pasal 6 diatur mengenai Nilai-Nilai Dasar Bagi Pegawai Negeri Sipil dinyatakan bahwa: Nilai-nilai Dasar yang harus dijunjung tinggi oleh Pegawai Negeri Sipil meliputi:

a. ketaqwaan kepada Tuhan Yang Maha Esa;

b. kesetiaan dan ketaatan kepada Pancasila dan Undang-Undang Dasar 1945;

c. semangat nasionalisme;

d. mengutamakan kepentingan negara di atas kepentingan pribadi atau golongan;

e. ketaatan terhadap hukum dan peraturan perundang-undangan;

f. penghormatan terhadap hak asasi manusia;

g. tidak diskriminatif;

h. profesionalisme, netralitas, dan bermoral tinggi;

i. semangat jiwa korps.

Nilai-nilai dasar Pegawai Negeri Sipil yang tercantum dalam Peraturan Pemerintah ini memperlihatkan adanya Ideologi Etis yang bersifat absolut. Hal ini semakin terlihat dalam Kode Etik Pegawai Negeri Sipil yang tercantum dalam Pasal 7, yang menyatakan bahwa:

"Dalam pelaksanaan tugas kedinasan dan kehidupan sehari-hari setiap Pegawai Negeri Sipil wajib bersikap dan berpedoman pada etika dalam bernegara, dalam penyelenggaraan Pemerintahan, dalam berorganisasi, dalam 
bermasyarakat, serta terhadap diri sendiri dan sesama Pegawai Negeri Sipil yang diatur dalalam Peraturan Pemerintah ini".

Khusus mengenai etika dalam berorganisasi diatur dalam Pasal 9. Pasal ini menyatakan bahwa Etika dalam berorganisasi adalah:

a. melaksanakan tugas dan wewenang sesai ketentuan yang berlaku;

b. menjaga informasi yang bersitat rahasia;

c. melaksanakan setiap kebijakan yang ditetapkan oleh pejabat yang berwenang;

d. membangun etos kerja untnk meningkatkan kinerja organisasi;

e. menjalin kerja sama secara kooperatif dengan unit kerja lain yang terkait dalam rangka pencapaian tujuan;

f. memiliki kompetensi dalam pelaksanaan tugas;

g. patuh dan taat terhadap standar operasional dan tata kerja;

h. mengembangkan pemikiran secara kreatif dan inovatif dalam rangka peningkatan kinerja organisasi;

i. berorientasi pada upaya peningkatan kualitas kerja.

Pengaturan yang terdapat dalam Pasal ini memberikan indikasi kuat adanya ideologi etis relative. Hal ini terlihat aturan tentang menjaga informasi rahasia. Aturan ini dapat disalahgunkan untuk menutupi suatu pelanggaran atau kejahatan seperti korupsi.

Dikaitkan dengan upaya untuk penguatan clean government, maka birokrasi yang ada pun harus direkonstruksi (ditata ulang) menyesuaikan kepentingan nasional (pemberantasan korupsi) dan kepentingan global (berkembangnya budaya etika whistleblowing). Upaya yang harus dilakukan adalah:

a. Revitalisasi Kode Etik Aparatur Sipil Negara (PP No. 42 tahun 2004 tentang Pembinaan Korps dan Kode Etik Pegawai Negeri Sipil).

b. Menyediakan saluran penyingkapan korupsi (whistleblowing mechanism) di setiap instansi pemerintah. Mekanisme whistleblowing dianggap penting karena dianggap sebagai metode yang paling berhasil dalam menemukan ad- anya korupsi, dibandingkan dengan metode lainnya.

\section{Penyingkap Korupsi Birokrasi Belum Terl- idungi Hukum}

Penelitian yang dilakukan oleh Milliken, Morrison, dan Hewlin menyatakan bahwa Karyawan sering enggan untuk berbagi informasi, karena dapat diartikan sebagai perbuatan negatif dan dapat mengancam kedudukan mereka dalam hierarki organisasi. Keengganan untuk berbicara, dan bersikap diam atas informasi berpotensi merusak pengambilan keputusan. Tindakan koreksi atas kesalahan organisasi akan merusak kepercayaan dan moral karyawan (Hewlin 2003:1454). Hal ini menunjukkan bahwa jika organisasi melakukan pembalasan terhadap penyingkap korupsi maka bukan hanya kesempatan untuk mengatasi kesalahan yang hilang, tapi tambahan kepercayaan dalam hubungan antara organisasi dan penyingkap korupsi menjadi rusak dan moral karyawanpun dirugikan. Hal ini dapat mengakibatkan penyingkap korupsi yang sedang putus asa untuk melaporkan, bahkan mungkin berdiam diri tidak mencari saluran eksternal. Memilih diam untuk mungkin melindunginya dari pembalasan, tapi konsekuensi jangka panjangnya biaya yang dipikulnya jauh lebih besar daripada manfaat jangka pendek yang memilih untuk tetap diam.

Situasi yang sama dapat ditemukan dengan penyingkap korupsi eksternal. Meskipun penyingkap korupsi eksternal dapat mengakibatkan banyak penderitaan bagi penyingkap korupsi untuk alasan yang sama seperti mereka yang tetap diam, hal ini mungkin lebih merugikan bagi organisasi dalam jangka panjang.

Oleh karena itu penyingkap korupsi yang diam dan penyingkap korupsi eksternal bukanlah pilihan optimal dalam menanggapi kesalahan. Di sisi lain, jika kepercayaan penyingkap korupsi bahwa organisasi akan bertindak atas masalah ini, dan tidak akan menimbulkan kerugian kepadanya, maka keinginannnya untuk tetap diam akan berkurang. Selanjutnya, karena pelaporan kepada otoritas dalam organisasi menawarkan kesempatan terbesar untuk tindakan korek- 
tif konstruktif dan akan terlihat merugikan setidaknya untuk pelapor, muncul pertanyaan akankah kepercayaan ini mendorong whistleblowing internal? Dapatkah efektivitas whistleblowing sebagai mekanisme pencegahan korupsi ditingkatkan melalui pelaporan internal yang dibangun di atas hubungan kepercayaan? Kepercayaan mungkin penting untuk memahami pilihan para penyingkap informasi dan karenanya patut lebih menjadi perhatian akademik dari apa yang telah diterima.

Dalam rangka menumbuhkan partisipasi masyarakat untuk mengungkap tindak pidana, perlu diciptakan iklim yang kondusif dengan cara memberikan perlindungan hukum dan keamanan kepada setiap orang yang mengetahui atau menemukan suatu hlm. yang dapat membantu mengungkap tindak pidana yang telah terjadi dan melaporkan hlm. tersebut kepada penegak hukum. Pelapor yang demikian itu harus diberi perlindungan hukum dan keamanan yang memadai atas laporannya, sehingga ia tidak merasa terancam atau terintimidasi baik hak maupun jiwanya. Dengan jaminan perlindungan hukum dan keamanan tersebut, diharapkan tercipta suatu keadaan yang memungkinkan masyarakat tidak lagi merasa takut untuk melaporkan suatu tindak pidana yang diketahuinya kepada penegak hukum, karena khawatir atau takut jiwanya terancam oleh pihak tertentu. Perlindungan Saksi dan Korban dalam proses peradilan pidana di Indonesia belum diatur secara khusus. Pasal 50 sampai dengan Pasal 68 Undang-undang Nomor 8 Tahun 1981 tentang Hukum Acara Pidana hanya mengatur perlindungan terhadap tersangka atau terdakwa untuk mendapat perlindungan dari berbagai kemungkinan pelanggaran hak asasi manusia. Itulah latar belakang dibentuknya UU No.13 Tahun 2006 Tentang Perlindungan Saksi dan Korban, yang diubah menjadi UU No.31 Tahun 2014.

Pelaporan atas pelanggaran, perbuatan melawan hukum, tidak etis, atau merugikan organisasi atau pemangku kepentingan haruslah dilakukan dengan itikad baik dan bukan merupakan keluhan pribadi atas suatu kebijakan institusi, atau bahkan dilandasi dengan itikad buruk atau fitnah. Sebenarnya, yang menjadi pelapor adalah karyawan atau orang dalam dari suatu institusi, akan tetapi tidak tertutup munculnya pelapor eksternal institusi yang menjadi konstituen institusi, misalnya konsumen, pelanggan, pemasok, masyarakat Sistem pelaporan ini tidak hanya dapat diterapkan pada institusi pemerintah, tetapi direkomendasi pula di institusi swasta.

Indonesia belum memiliki peraturan khusus yang secara komprehensif mengatur sistem pelaporan pelanggaran sebagai sebuah sistem. Namun, ada beberapa peraturan perundangan yang secara parsial mengatur pelaporan pelanggaran dan perlindungan pelapor. Beberapa di antaranya, Pasal 9 UU No. 28 Tahun 1999 tentang Penyelenggaraan Negara yang Bersih dan Bebas dari Korupsi, Kolusi, dan Nepotisme; Pasal 31 dan 41 Ayat (2) Butir e UU No. 31 Tahun 1999 tentang Pemberantasan Tindak Pidana Korupsi; Pasal 39-43 UU No. 15 Tahun 2002 jo. UU No. 25 Tahun 2003 tentang Tindak Pidana Pencucian Uang; Pasal 153 Ayat (1) Huruf 1 dan Pasal 158 Ayat (1) Huruf I UU No. 13 Tahun 2003 tentang Ketenagakerjaan; Pasal 10 Ayat 1 UU No. 13 Tahun 2006 tentang Perlindungan Saksi dan Korban; PP No. 57 Tahun 2003 tentang Tata Cara Perlindungan Khusus.

Para penyingkap korupsi yang berasal dari Jawa Tengah juga menghadapi kondisi yang tidak terlindungi oleh hukum. Hukum hanya memberikan perlindungan apabila sudah masuk dalam proses peradilan pidana, sementara jika belum masuk dalam proses peradilan pidana maka tidak ada perlindungan. Disamping perlindungan untuk pelapor hanya terbatas untuk tindak pidana tertentu, seperti dalam tindak pidana pencucian uang, hal ini pun terkadang belum difahami secara terintegrasi di kalangan aparat penegak hukum yang menjalankan sistem peradilan pidana.

Berbagai perlakuan yang tidak adil diterima oleh para aparatur sipil negara sebagai bentuk reaksi atas sikapnya yang berperan menjadi penyingkap korupsi. Akibat perlakuan yang dihadapi oleh mereka ada yang tetap bertahan sebagai aparatur sipil negara, keluar karena merasa tidak tepat bekerja di lingkungan birokrasinya dan bahkan diber- 
Tabel 4. Akibat Tidak Adanya Perlindungan Bagi Penyingkap Korupsi

\begin{tabular}{llll}
\hline \multicolumn{1}{c}{ Informan } & \multicolumn{1}{c}{ Motivasi } & \multicolumn{1}{c}{ Perlakuan Yang Dialami } & \multicolumn{1}{c}{ Kondisi Sekarang } \\
\hline $\begin{array}{l}\text { Sugeng } \\
\text { Ibrahim }\end{array}$ & $\begin{array}{l}\text { Idealisme akan } \\
\text { kebenaran dan } \\
\text { keadilan }\end{array}$ & $\begin{array}{l}\text { Diancam dibunuh, dipecat, } \\
\text { diasingkan dalam pergaulan }\end{array}$ & $\begin{array}{l}\text { Keluar dari PNS tahun 1999 } \\
\text { dan Wiraswasta }\end{array}$ \\
& $\begin{array}{l}\text { Idealisme akan } \\
\text { kebenaran dan } \\
\text { keadilan }\end{array}$ & Diancam dibunuh dan dipecat & $\begin{array}{l}\text { Kepala SMPN 1 Mojolaban } \\
\text { Sukoharjo }\end{array}$ \\
Purwanto & Idealisme akan \\
kebenaran dan & $\begin{array}{l}\text { Diancam dibunuh, diasingkan, } \\
\text { dimutasi tanpa alasan yang } \\
\text { jelas dan berakhir dengan } \\
\text { keadilan }\end{array}$ & $\begin{array}{l}\text { Menjadi pengajar di sekolah } \\
\text { swasta dan membuka } \\
\text { kursus bahasa Inggris }\end{array}$ \\
& & 2010 & \\
\hline
\end{tabular}

hentikan tidak atas kemauan sendiri.

Beberapa kendala yang dirasakan LPSK atas pelaksanaan UU No.31 Tahun 2014 diantaranya, 1 ) belum adanya perlindungan terhadap pelapor atau penyingkap korupsi dalam ketentuan $U U, 2)$ belum adanya pengaturan mengenai pembentukan LPSK daerah, 3) belum adanya pengaturan yang terkait pemberian perlindungan dan peran kolaborasi dengan aparat penegak hukum lainnya, 4) belum maksimalnya pengaturan mengenai kelembagaan LPSK, dan 5) perlu adanya redefinisi ulang terhadap penyingkap korupsi (whistleblower) di sesuaikan dengan ketentuan hukum internasional. Perlindungan hukum seharusnya diberikan oleh organisasi/ birokrasi dan sistem peradilan pidana sendiri. Ketiadaan perlindungan hukum yang akan menyurutkan semangat pemberantasan korupsi dan sekaligus menciptakan peluang pelanggaran HAM. Jika ini terjadi, maka fungsi hakiki dari hukum yang bersifat melindungi ternyata sudah mengalami disfungi atau bahkan malfungsi. Hukum tidak lagi bertujuan mengayomi dan menciptakan keadilan melainkan justru menzalimi dan menindas.

Ketiadaan perlindungan hukum dalam birokrasi akan melahirkan pembalasan bagi para penyingkap korupsi. Sedangkan ketiadaan perlindungan hukum di dalam sistem peradilan pidana akan melahirkan ketidakadilan hukum bagi para penyingkap korupsi. Suara kebenaran akan tenggelam dalam arus kuat kekuasaan yang korup dan peradilan yang tidak obyektif.

\section{Simpulan}

Keberadaan peran whistleblower (penyingkapkorupsi) dalam pemberantasan korupsi semakin dirasakan kepentingannya apalagi di lingkungan birokrasi pemerintah. Mereka berperan untuk mendeteksi dugaan adanya korupsi yang sudah, sedang atau telah terjadi di suatu birokrasi. Upaya-upaya untuk melindungi mereka pada hakekatnya merupakan bagian dari upaya pemberantasan korupsi. Seorang aparatur sipil negara dapat berperan sebagai "penyingkap korup$\mathrm{si}^{\prime \prime}$, tatkala dia meyakini adanya perbuatan korupsi yang terjadi di lingkungan kerjanya, kemudian dia mengungkapkan pelanggaran yang terjadi itu kepada pimpinan birokrasinya atau otoritas publik lainnya dengan harapan agar perbuatan korupsi tersebut dapat dihentikan. Inilah peran penting dari Ideologi Etis yang dimiliki aparatur sipil negara. Alasan aparatur sipil negara di Jawa Tengah yang menyingkap dugaan korupsi lingkungan birokrasinya karena alasan yang muncul dari pribadi mereka masing-masing serta alasan lingkungan dimana mereka bekerja. Tipologi Ideologi Etis yang dimiliki para penyingkap korupsi di Jawa Tengah adalah Idealism Absolutits karena mereka meyakini bahwa korupsi itu harus dicegah dan dilawan karena bertentangan dengan nilai-nilai moral yang universal.

\section{Daftar Pustaka}

Ajzek, Icek, 1991, The Theory of Planned Behavior, Organizational Behavior And Human Decision Processes, Department of Psychology, Univer- 
sity of Massachusetts

Asshiddiqie, Jimly, 2013, Perkembangan Sistem Norma Menuju Terbentuknya Sistem Peradilan Etika www.jimly.com/makalah/namafile /178/ Jurnal_MIPI_tentang_Etika.pdf

Awaludin, Arif, 2011, Rekonstruksi Perlindungan Hukum Terhadap Penyingkap Korupsi (Studi Kasus Budaya Hukum Aparatur Sipil Negara Dalam Menyingkap Korupsi Birokrasi Di Jawa Tengah), Disertasi, Semarang: PDIH UNDIP

Brink, Alisa G. et.all, 2015, The Effects of Personality Traits, Ethical Position, and the Materiality of Fraudulent Reporting on Entry-level Employee Whistleblowing Decisions, Journal of Forensic \& Investigative Accounting Vol. 7, Issue 1.

Caswell, S. V. 2003. Individual Moral Philosophies And Ethical Decision-Making Of Undergraduate Athletic Training Education Students And Instructors. (Unpublished doctoral dissertation). Ohio University, USA

Chan, C. L. M., Othman, J., \& Jones, R. 2011. The Conceptual Model of Personal Moral Philosophy (PMP) and Ethical Decision Making (EDM). Journal of Management Research, 3(2). http:// dx.doi.org/10.5296/jmr.v3i2.752

Forsyth, D. R. (1980). A Taxonomy Of Ethical Ideologies. Journal of Personality and Social psychology, 39(1).

Forsyth, D. R., O'Boyle Jr, E. H., \& McDaniel, M. A. 2008. East Meets West: A Meta-Analytic Investigation Of Cultural Variations In Idealism And Relativism. Journal of Business Ethics, 83(4), 813

Gordon Graham, 2010, Theories of Ethics: An Introduction to Moral Philosophy, Routledge.

Lin, C.-P., \& Ding, C. G. 2003. Ethical Ideology, Subjective Norm, and Peer Reporting Intentions using An Individual-Situation Moderator. Asia Pacific Management Review, 8(3), 311

Mertins, Herman Eds. 1999, Applying Professional Standards and Ethics in the 21st Century, Amnerican Society for Public Administration
Muhaimin, Yahya, 1990, BisnisdanPolitik“Kebijaksanaan Ekonomi Indonesia 1950 - 1980", LP3ES: Jakarta

Pekdemir, Isıl Mendes dan Aygül Turan, 2015, The Influence of Ethical Ideologies on Promotive Extra Role Behaviors and Positive Work Behavior of Individuals. International Journal of Business and Social Research Volume 05, Issue 08.

Pope, Jeremy, 2003 Strategi Memberantas Korupsi, Edisi Ringkas, Diringkas oleh Tjahjono EP, Jakarta: Tranparansi Internasional

Rahardjo, Satjipto, 2005, Mengadili Korupsi Mengapa Dipersulit, Jakarta: Penerbit Buku Kompas

Rehg, M.T., Miceli, M.P., Near, J.P. and Van Scotter, J.R., 2008, "Antecedents and outcomes of retaliation against whistleblowers: gender differences and power relations", Organization Science, Vol. 19 No. 2,

Sanit, Arbi, 2006, dalam Tim Simpul Demokrasi. Reformasi Birokrasi dan Demokratisasi Kebijakan Publik. Malang: Averroes Press.

Schlenker, B. R., 2008. Integrity And Character: Implications Of Principled And Expedient Ethical Ideologies. Journal of Social and Clinical Psychology, 27(10).

Sudimin, Theo, 2003, Whistleblowing; Dilema Loyalitas dan Tanggung Jawab Publik, Jurnal Manajemen dan Usahawan, Vol 32-11.

Supeno, Hadi, 2010, Korupsi di Daerah: Kesaksian, Pengalaman, dan Pengakuan, Yogyakarta: Total Media

Internet

http://www.acfe.com Diakses terakhir pada 31 Agustus 2016

http://www.detiknews,com, Melaporkan Pungli di Dinas Pendidikan, Guru di Sukoharjo Terancam Dipecat, 21 Januari 2010

http://www.oxfordadvancedlearnersdictionary.com/ dictionary/whistleblower, diakses pada $10 \mathrm{Ma}-$ ret 2011 